\title{
UPAYA MENGATASI TANTANGAN PENDIDIKAN ISLAM PADA ABAD XXI
}

\author{
Hadiyatan Wasilah \\ Mahasiswa Program Studi Magister Pendidikan Islam \\ Sekolah Pascasarjana Universitas Muhammadiyah Surakarta \\ Email: hadiyatan621@gmail.com
}

\begin{abstract}
Abstrak: Pendidikan Islam telah berkembang dari masa ke masa, hingga sampai pada abad XXI di mana pada abad ini globalisasi telah menjadi realitas yang dihadapi setiap individu. Namun terdapat dampak negatif yang ditimbulkan oleh globalisasi di antaranya semakin banyaknya generasi muda yang melakukan seks bebas, penggunaan obat terlarang, hilangnya norma-norma dalam kehidupan. Hal ini tentu menjadi beban bagi dunia pendidikan khususnya pendidikan Islam karena pendidikan merupakan upaya sebagai proses perkembangan individu baik pada tataran moral maupun intelektual. Olehnya perlu dilakukan upaya dalam mengatasi tantangan serta problematika tersebut. Upaya dalam mengatasi tantangan pendidikan abad XXI diklasifikasikan bagi pemangku kebijakan pendidikan yang meliputi: 1) membangun orientasi dan visi pendidikan Islam; 2)integrasi antara ilmu agama dan umum; 3) pengembangan tradisi akademik. Klasifikasi kedua adalah upaya bagi Guru dalam pendidikan Islam yang meliputi: 1) reorientasi visi dan misi guru; 2) strategi pembelajaran; 3) penanaman serta penerapan nilainilai keislaman.
\end{abstract}

Kata Kunci: tantangan, pendidikan Islam, abad XXI 


\section{PENDAHULUAN}

$\mathrm{U}$ mat Islam telah mengimpikan bagaimana terwujudnya pendidikan Islam yang berkemajuan dan telah banyak upaya yang dilakukan untuk menggapainya, mulai integrasi Islam dan sains, islamisasi ilmu, "ilmuisasi" Islam dan lain sebagainya. Hanya saja hal ini belum dioptimalkan oleh umat Islam sendiri tersebab kungkungan ideologi-ideologi Barat yang masuk pada sendi-sendi kehidupan umat Islam, sehingga pada tatanan realitas dunia pendidikan, pola pendidikan Islam masih tertinggal dari pendidikan sekuler.

Ekspektasi kemajuan pendidikan Islam tidak pernah lenyap dalam cita-cita umat Islam umumnya dan pemikir serta praktisi pendidikan Islam khususnya, karena kesadaran bahwa kemajuan pendidikan Islam akan berfungsi strategis baik dalam ranah politik, ekonomi, sosial serta kultural. ${ }^{1}$

Faktanya pada abad XXI pendidikan Islam terus menerus berupaya menjawab tantangan globalisasi di mana hari ini dampaknya telah terlihat sangat jelas berupa integrasi ekonomi, fragmentasi politik, high technology, interdependensi antar bangsa, dan new colonization in culture. ${ }^{2}$

1 Mujamil Qomar, Strategi Pendidikan Islam, (Jakarta: Erlangga, 2013), hlm. 2

${ }^{2}$ Abuddin Nata, Kapita Selekta Pendidikan Islam IsuIsu Kontemporer tentang Pendidikan Islam, (Depok: Raja Grafindo Persada, 2012), hlm. 263
Tentulah diperlukan upaya-upaya strategis dalam Pendidikan Islam yang berfungsi sebagai filter umat Islam dalam menerima berbagai pemikiran serta pola hidup masyarakat di era globalisasi pada abad XXI ini yang digerakkan oleh berbagai ideologi barat seperti pragmatism, hedonism, rasionalism, dan materialism di mana pemikiranpemikiran tersebut menjauhkan manusia akan peran Tuhan. ${ }^{3}$ Di mana dalam pendidikan Islam tujuan pendidikan yang paling utama adalah bagaimana manusia mengenal Tuhan serta kesadaran penuh akan kehadiran-Nya.

\section{Fenomena Globalisasi Sebagai Tan-} tangan Pendidikan Islam Pada Abad 21

Globalisasi didefinisikan oleh Joseph Stiglitz dikutip Muhaimin adalah semakin dekatnya integrasi antar bangsa dan negara di dunia yang disebabkan oleh runtuhnya batas-batas tak kasat mata yang disebabkan arus modal, jasa, pengetahuan dan manusia yang saling melintas antar perbatasan. ${ }^{4}$ Pengertian lain dijelaskan oleh Robertson dalam Faisal Ismail di mana globalisasi adalah pemadatan dunia menjadi satu ruang

\footnotetext{
${ }^{3}$ Ibid., hlm. 264

4 Muhaimin, Pemikiran dan Aktualisasi Pengembangan Pendidikan Islam, (Jakarta: Raja Grafindo Persada, 2011), hlm. 91
} 
tunggal dan terjadi peningkatan kesadaran tentang dunia sebagai satu kesatuan. ${ }^{5}$

Fenomena globalisasi terjadi berkat kemajuan teknologi komunikasi, informasi, serta transportasi modern dan canggih yang mampu dengan cepat dan mudah menghubungkan satu negara ke negara yang lain walaupun letaknya berjauhan satu sama lain. Tentunya hal ini memudahkan manusia dalam berinteraksi antar bangsa sehingga tersentuhnya sosiokultural dan edukasional antar manusia dan bangsa. Demikian pula dengan teknologi informasi serta komunikasi yang modern dan canggih sehingga manusia dapat dengan mudah menerima informasi baik dari media cetak maupun elektronik, yang menjadikan dunia sebagai global village yang dapat dijangkau dengan mudah tersebab kemajuan teknologi tersebut. ${ }^{6}$

Abuddin Nata menjelaskan dampak yang ditimbulkan oleh globalisasi pada era ini menimbulkan fenomena berikut ini: ${ }^{7}$

Proses integrasi ekonomi yaitu sebuah kondisi terbukanya perdagangan di antara bangsa-bangsa seluruh dunia yang menjadikan suatu bangsa menjadi pasar produk bangsa lain atau sebaliknya. Hal ini menyebabkan persaingan dagang yang ketat dan kurang sehat antar bangsa sehingga

\footnotetext{
${ }^{5}$ Faisal Ismail, Paradigma Pendidikan Islam Analisis Historis, Kebijakan dan Keilmuan, (Bandung: Rosda, 2017), hlm. 249

${ }^{6}$ Ibid.
}

menghalalkan segala cara demi memperoleh keuntungan sebesar-besarnya dalam perekonomian.

Fragmentasi politik merupakan suatu kondisi penuntutan oleh tiap-tiap individu untuk diperlakukan secara lebih adil, demokratis, manusiawi, serta egaliter. Keadaan demikian menjadikan tindakan yang dipandang melanggar hak asasi manusia akan mendapatkan penolakan yang terkadang dilakukan dengan cara yang berlebihan dan cenderung bersikap anarkis.

High teghnology yaitu fenomena serta realitas semakin canggihnya teknologi, yang memudahkan kegiatan manusia sehari-hari, utamanya dalam bidang komunikasi dan informasi yang mengubah pola komunikasi antar manusia yang lebih bersifat jarak jauh serta penyalahgunaan teknologi untuk tujuan yang merusak moral, kriminal dan lain sebagainya.

Interdependensi merupakan keadaan di mana antar bangsa-bangsa di dunia sudah saling membutuhkan antara satu dengan yang lainnya dalam rangka memenuhi kebutuhan hidup. Kondisi ini menimbulkan kerja sama antar bangsa yang realitasnya kerja sama ini diwarnai saling mendominasi antara satu yang lain.

\footnotetext{
${ }^{7}$ Abuddin Nata, Kapita Selekta Pendidikan Islam IsuIsu Kontemporer tentang Pendidikan Islam, (Depok: Raja Grafindo Persada, 2012), hlm. 263265
} 
New colonization and culture merupakan fenomena suatu budaya bangsa tertentu lebih menguasai budaya bangsa lain yang menyebabkan tergesernya budaya suatu bangsa oleh budaya bangsa tertentu, hal ini disebabkan salah satunya oleh kecanggihan teknologi yang memudahkan manusia untuk mengakses serta mendapatkan berbagai informasi. Dampak buruknya tentunya mempengaruhi berbagai hal seperti pola pergaulan, gaya hidup, serta pola komunikasi yang tidak sesuai dengan budaya bangsa sendiri, fenomena ini terlihat bagaimana maraknya seks bebas di antara muda mudi, penyalahgunaan narkoba, gaya hidup yang bersifat hedonisme sehingga menghalalkan segala cara untuk memenuhi kebutuhan serta tindakan amoral lainnya.

Fenomena-fenomena tersebut telah menjadi momok menakutkan bagi masyarakat, sehingga perlu upaya dalam mengentaskannya. Dalam hal ini pendidikan merupakan gerbang utama dalam menjawab tantangan-tantangan tersebut, lebih khususnya dalam Islam pendidikan merupakan sarana yang paling strategis dalam mengangkat harkat dan martabat manusia dalam seluruh proses kehidupan serta sarana menyempurnakan akhlak manusia. Hal ini telah jelas termaktub dalam perintah Allah dalam wahyu pertama yang diturunkan yaitu surat al-Alaq ayat 1-5 yang mengisyaratkan tentang pentingnya pendidikan: ${ }^{8}$

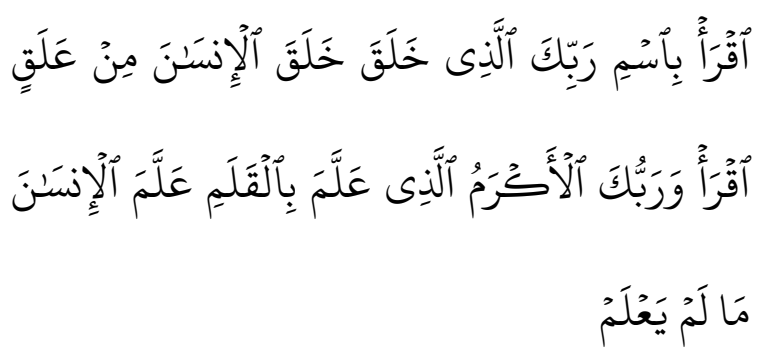

Bacalah dengan (menyebut) nama Tuhanmu yang Menciptakan, Dia telah menciptakan manusia dari segumpal darah. Bacalah, dan Tuhanmulah yang Maha pemurah, yang mengajar (manusia) dengan perantaraan kalam. Dia mengajar kepada manusia apa yang tidak diketahuinya.

Dengan demikian pendidikan Islam haruslah berupaya mengentaskan tantangantantangan yang ditimbulkan globalisasi, sehingga terwujudnya masyarakat yang mampu menanamkan nilai-nilai Islam dengannya mampu menjadi filter mana budaya yang dapat dikonsumsi dan mana budaya yang cukup menjadi pengetahuan untuk membentengi diri dalam berkehidupan di era globalisasi pada abad XXI.

\section{Upaya Pendidikan Islam dalam} Mengatasi Tantangan Globalisasi Abad Ke XXI

Pembahasan kali ini akan dipaparkan bagaimana upaya pendidikan Islam yang

\footnotetext{
${ }^{8}$ Abuddin Nata, Kapita Selekta....., hlm. 8
} 
ditawarkan dalam menghadapi tantangan globalisasi pada abad XXI yang akan penulis bagi dalam dua pembahasan, pertama upaya yang dilakukan oleh pemangku kebijakan pendidikan Islam, dan yang kedua upaya yang dilakukan oleh guru pendidikan Islam dalam menangani tantangan-tangan globalisasi tersebut.

\section{Bagi Pemangku Kebijakan Pendidikan Islam}

a. Membangun Orientasi dan Visi Pendidikan Islam

Dampak globalisasi sejatinya sedikitdemi sedikit mengubah pola pikir masyarakat dalam memahami segala hal yang dalam prosesnya menjadikan orientasi pendidikan adalah sarana mendapatkan pekerjaan serta kehidupan yang layak. Lebih lanjut lagi Abuddin Nata menjelaskan dampak globalisasi menyebabkan terjadinya perubahan pola pikir masyarakat yang pada awalnya memahami pendidikan adalah sebuah proses untuk meningkatkan intelektual, moral, fisik dan psikis menjadi bagaimana mendapatkan pekerjaan dan penghasilan besar setelah melewati proses pendidikan. $^{9}$

Fenomena tersebut tentu membutuhkan upaya para pemangku kebijakan pendidikan

\footnotetext{
${ }^{9}$ Abuddin Nata, Kapita Selekta....., hlm. 17

${ }^{10}$ Faisal Ismail, Paradigma Pendidikan .....,hlm. 3

11 Dikutip oleh Veitzal Rivai Zainal, Fauzi Bahar, Islamic Education Management Dari Teoritik ke
}

Islam untuk membangun orientasi dan visi pendidikan Islam yang tentunya mampu mengubah konsep pendidikan yang hanya berorientasi pada pemahaman materialism, di mana Faisal Ismail memberikan konsep pendidikan Islam sebagai berikut:

"Pendidikan Islam adalah totalitas kegiatan manusia yang dilakukan secara sungguh-sungguh, sadar, terencana, terstruktur, dan berkesinambungan atas dasar iman dan takwa kepada Allah SWT. Dalam rangka menghasilkan anak-anak didik menjadi sumber daya manusia yang memiliki mental, karakter, dan kepribadian yang kuat dan utuh serta berkualitas secara intelektual dan berkualitas secara moral sebagai modal untuk dapat hidup secara mandiri." 10

Pendidikan Islam juga dijelaskan oleh Hasan Langgulung sebagai suatu proses pembentukan individu berdasarkan ajaranajaran Islam yang diwahyukan Allah kepada Nabi Muhammad SAW sehingga dapat mencapai derajat yang tinggi yaitu menjadi khalifah di muka bumi, yang dalam prosesnya melalui transfer pengetahuan dan nilai-nilai Islam. ${ }^{11}$

Konsep yang diajukan di atas tentulah berbeda dengan bagaimana mayoritas masyarakat memandang tujuan atau

Praktik Mengelola Pendidikan Secara Profesional dalam Perspektif Islam, (Depok: Raja Grafindo, 2013), hlm. 73 
orientasi pendidikan di mana dalam pendidikan Islam dasar utamanya adalah proses mengenal Allah lewat keimanan serta ketakwaan yang dengannya menjadikan peserta didik menjadi manusia yang utuh baik dalam intelektual maupun moral sebagai perannya menjadi khalifah di muka bumi.

Tentunya tidak cukup bagi pendidikan Islam dengan hanya menyiapkan sumber daya manusia siap pakai, namun juga mampu melestarikan nilai-nilai luhur dan memperbaiki penyimpangan yang diakibatkan oleh pengaruh globalisasi. ${ }^{12}$ Lebih lanjut lagi berkat dampak dari globalisasi maka seharusnya visi dan orientasi pendidikan bukan hanya menekankan pada pengasahan intelektual saja, namun juga pengisian jiwa, pembinaan akhlak, dan kepatuhan dalam menjalankan ibadah. ${ }^{13}$ Maka orientasi dan visi inilah yang harus diperjuangkan pemangku kebijakan pendidikan Islam di era globalisasi.

\section{b. Integrasi Antara Ilmu Agama dan Umum}

Telah menjadi realitas di seluruh penjuru negeri yang dihuni oleh umat Islam

\footnotetext{
${ }^{12}$ Abuddin Nata, Manajemen pendidikan Mengatasi Kelemahan pendidikan di Indonesia, (Jakarta: Kencana, 2012), hlm. 99

${ }^{13}$ Ibid., hlm. 100

14 Israr, Ahmad Khan, Towards Understanding Islamic Paradigm of Education, https://i-
}

bahwa terdapat dikotomi antara apa yang disebut dengan ilmu pengetahuan dengan ilmu Agama, hal ini menjadikan ilmu-ilmu tersebut diklasifikasikan sebagai keilmuwan ukhrawi yang bersifat sakral dan keilmuan sekuler yang bersifat duniawi (materialism), dimana pada ilmu-ilmu sekuler kiblat utamanya adalah pemikiran barat yang sangat bertolak belakang dengan nilai-nilai Islam.

Fenomena tersebut telah disanggah oleh Israr Ahmad Khan, yang menyatakan bahwa ilmu-ilmu yang dibentangkan Allah kepada manusia sama-sama bersifat sakral karena dengan pengembangan ilmu ilmu tersebut manusia mendapat kemudahan untuk memenuhi tugasnya sebagai pemimpin dimuka bumi (khalifah fil ardh). ${ }^{14}$ Lebih lanjut Abuddin Nata menjelaskan integrasi antara keduanya perlu dilakukan tanpa mengorbankan spesialisasi yang telah menjadi ciri khas masyarakat modern dengan cara menghubungkan antara kedua ilmu tersebut, karena faktanya mayoritas masyarakat di era modern tidak mampu untu menguasai segala bidang keilmuan. ${ }^{15}$

Mengatasi fenomena tersebut maka muncul paradigma-paradigma mengenai integrasi keilmuan antara keduanya seperti

epistemology.net/subjects/education/item/606towards-understanding-islamic-paradigm-ofeducation.html, (diakses pada tanggal 31 Oktober 2019, pukul 18.30 WIB)

15 Abuddin Nata, Manajemen pendidikan....., hlm. 104 
islamisasi ilmu yang dipopulerkan oleh Ismail Raji Alfaruqi dan Naquib Al-Attas dengan tujuan agar umat Islam tidak begitu saja meniru metode-metode dari luar dengan mengembalikan pengetahuan pada pusatnya, yaitu tauhid. Serta pengilmuan Islam yang digagas oleh Kuntowijoyo. Paradigma tersebut bertujuan untuk menghubungkan kembali teks dengan konteks agar keduanya terdapat kesinambungan, karena dewasa ini agama seakan kehilangan kontak dengan kenyataan, realitas, aktualitas maupun kehidupan. ${ }^{16}$ kedua konsep paradigma tersebut bertujuan untuk mengarahkan umat Islam kembali pada teks wahyu (al-Qur'an dan Sunnah) sebagai rujukan utama dalam berkehidupan di Dunia termasuk dalam mengembangkan pengetahuan.

Paradigma yang telah tersedia tersebut adalah upaya pengintegrasian ilmu pengetahuan yang telah diklasifikasikan akibat dari kehidupan modern yang menuntut spesialisasi yang berlebihan. Integrasi keilmuan juga perlu dilakukan untuk menghindari dan mencegah timbulnya sekularisme dalam pengetahuan serta penting dilakukan dalam rangka menghasilkan generasi yang utuh serta berpikir integrated. $^{17}$

\footnotetext{
${ }^{16}$ Kuntowijoyo, Islam Sebagai Ilmu Epistemologi, Metodologi, dan Etika, (Yogyakarta: Tiara Wacana, 2007), hlm. 5-6

17 Abuddin Nata, Manajemen pendidikan....., hlm. 104
}

c. Pengembangan Tradisi Akademik

Kemajuan pengetahuan barat disebabkan oleh tradisi akademik yang dijunjung tingi dalam lembaga pendidikan. Penelitianpenelitian yang melahirkan penemuan teknologi canggih yang dinikmati seluruh manusia di dunia adalah hasil tradisi akademik yang bukan saja melalui transfer pengetahuan, dan menghafal namun juga karena pengembangan penelitian yang berkelanjutan.

Perlulah kiranya bagi pemangku serta praktisi kebijakan pendidikan Islam hendaknya mengembangkan tradisi akademik, budaya ilmiah dan mental keilmuan yang kuat pada pendidik maupun peserta didik. ${ }^{18}$ Mental keilmuan yang kuat diperoleh melalui pemahaman pengetahuan secara cermat dan teliti, selanjutnya dikembangkan melalui penelitian yang di dalamnya tercakup observasi dan analisis kritis sehingga dari tahap tersebut kualitas keilmuan didapatkan. ${ }^{19}$

\section{Bagi Guru dalam Pendidikan Islam}

a. Reorientasi visi dan misi Guru

Guru merupakan komponen penting dalam pelaksanaan pendidikan, sejarah telah

\footnotetext{
${ }^{18}$ Faisal Ismail, Paradigma Pendidikan .....,hlm. 260

19 Israr, Ahmad Khan, Towards Under standing.....(diakses pada tanggal 01 November 2019, pukul 20.30 WIB)
} 
mencatat bahwasanya sebelum teknologi berkembang serta sumber belajar masih sangat terbatas, guru memiliki peran dan fungsi dominan dalam mendapatkan pengetahuan.

Fenomena yang terjadi pada masyarakat pada era abad XXI adalah fenomena perkembangan teknologi khususnya informasi dan komunikasi yang semakin canggih yang menyebabkan penerapannya mau tidak mau harus dilakukan dan dikembangkan. Sebagai contoh diterapkannya media elektronika jarak jauh, sistem sekolah terbuka, penggunaan modul sebagai sarana belajar mandiri, membentuk persepsi baru mengenai peran guru yakni guru yang hanya dipersepsikan sebagai fasilitator pembelajaran. $^{20}$

Abuddin Nata lebih lanjut menyebutkan bahwa dampak kemajuan dan ilmu teknologi serta budaya global adalah semakin mengecilnya peran dan fungsi guru, karena banyak tugas keguruan seperti penyampaian informasi dan pendidikan keterampilan yang telah tergantikan oleh teknologi, kemudian sakralitas guru semakin tergeser guru sudah semakin tidak dihargai dan dihormati, nasihatnya tidak lagi didengarkan, tersebab peran guru bergeser pada fungsi kebendaan

\footnotetext{
${ }^{20}$ Kamrani Buseri, Antologi Pendidikan Islam dan Dakwah, Pemikiran Teoritis Praktis Kontemporer, (Yogyakarta: UII Press, 2003), hlm. 4
}

seperti fasilitator, katalisator, dan mediator. $^{21}$

Realita disorientasi tersebut juga menyerang pada pribadi-pribadi guru, di mana guru sebagai tenaga profesional hanya terlihat sebagai pekerjaan yang tunduk pada hukum transaksional materialistik, yaitu mengukur peran dan fungsinya hanya dengan jabatan yang diberikan kepadanya dan bayaran yang diterimanya. ${ }^{22}$ Lebih banyak terlihat guru lebih mementingkan administrasi pembelajaran untuk mendapatkan sertifikasi daripada memperhatikan bagaimana perkembangan kualitas intelektual serta spiritual peserta didik, di mana hal tersebut merupakan tugas utama seorang guru.

Permasalahan disorientasi di atas membutuhkan reorientasi visi dan misi guru dalam pendidikan, di mana Abudin Nata telah merancang visi dan misi orisinil sosok guru yang terkandung dalam ayat-ayat alQur'an: ${ }^{23}$

1. Visi dan misi Ulul al-bab (surat Ali Imran ayat 190-191), kandungan ayat ini menjelaskan bahwasanya visi guru sebagai ulul al-bab adalah menjadi manusia yang memiliki keseimbangan antara daya pikir dan daya nalar dengan daya zikir dan

\footnotetext{
${ }^{21}$ Abuddin Nata, Kapita Selekta....., hlm. 345

${ }^{22}$ Ibid.

${ }^{23}$ Ibid., hlm. 347-351
} 
spiritual. Dengan daya tersebut maka guru mempunyai mengembangkan misi untuk melakukan amar ma'ruf nahi munkar hal tersebut menjadikan sosok guru sebagai pembangun peradaban Islam.

2. Visi dan misi al-Ulama (surat Fathir ayat 27-28), kandungan ayat ini menjelaskan bahwasanya sebagai ulama, guru merupakan sosok yang mendalami ilmu pengetahuan melalui penelitian terhadap alam semesta. Hal ini merupakan upaya menghadirkan kesadaran bahwasanya Allah merupakan penguasa alam semesta di mana dengan hasil-hasil penelitian yang dikembangkan kesadaran bahwa teori serta fakta-fakta yang terdapat pada alam semesta ini merupakan tanda-tanda kekuasaanNya. Lewat hal tersebut muncullah rasa takut untuk menyalahgunakan ilmu yang dianugerahkan Allah kepadanya. Maka visi seorang guru adalah menjadi seorang ilmuwan yang mempunyai rasa takut kepada Allah dan melaksanakan misi untuk menggunakan ilmunya untuk kemajuan masyarakat. Maka dalam hal ini dalam Islam seorang guru bukan hanya sosok yang menguasai pengetahuan melainkan bagaimana dengan pengetahuan keilmuan tersebut mampu untuk menuntun dirinya pribadi maupun masyarakat untuk patuh serta tunduk kepada Allah SWT.

3. Visi dan misi al-Muzakki (surat alBaqarah ayat 129), kandungan ayat ini menjelaskan bahwasanya visi guru sebagai al-Muzakki adalah menjadi manusia yang memiliki karakter serta mental yang mulia. Sedang misinya adalah membersihkan diri serta anak didiknya dari karakter yang tercela serta menjauhkan di dari dosa dan maksiat yang dilarang Allah SWT dan RasulNya.

4. Visi dan misi ahl al-dzikr (surat alAnbiya ayat 7), kandungan ayat tersebut menjelaskan bahwasanya visi guru sebagai ahl al-dzikr adalah menjadi orang yang menguasai ilmu pengetahuan dan memiliki expert judgment. Artinya penguasaan pengetahuan tersebut mendapatkan pengakuan sebagai pakar atau ahli sehingga mempunyai otoritas untuk menilai, mengakui, atau membatalkan sebuah temuan ilmiah. Maka seorang ahl al-dzikr mengemban misi memperbaiki, membimbing, meluruskan, mengingatkan dan memberi keputusan atas perilaku 
yang dilakukan oleh peserta didiknya.

5. Visi dan misi al-rasikhuna fi al-ilm (surat al-Nisa ayat 162), kandungan ayat tersebut bahwa visi al-rasikhuna fi al-ilm adalah sosok guru yang bukan hanya mempunyai penguasaan terhadap pengetahuan dalam ranah data dan fakta, namun juga mempunyai kemampuan untuk memberi makna, pesan ajaran, spirit, kandungan, serta hakikat tentang pengetahuan tersebut. Dengan visi tersebut maka seorang guru mengemban misi untuk memberi makna, semangat dan dorongan kepada peserta didik dan masyarakat sekitarnya untuk meningkatkan kualitas hidup dengan menghayati, memahami makna yang terkandung dalam kehidupan.

Visi dan misi di atas menjelaskan bahwa fungsi guru tidak dapat digeser serta dikesampingkan dalam dunia pendidikan dengan hanya menjadikan sosok guru sebagai fasilitator dalam pembelajaran, karena lebih dari itu sosok guru merupakan penyambung tongkat estafet dalam misi kenabian yaitu sebagai penyempurna akhlak manusia.

24 Abuddin Nata, Manajemen pendidikan....., hlm. 102 b. Strategi Pembelajaran

Menyikapi tantangan globalisasi di abad XXI, seyogyanya guru telah merancang strategi pembelajaran yang tepat untuk mengembangkan potensi peserta didik. Jika dilihat selama ini guru cenderung menyelenggarakan pembelajaran dengan menggunakan pendekatan dogmatis, di mana peserta didik diberikan informasi serta pengetahuan tanpa diberi kesempatan untuk menyampaikan pendapat secara kritis dan rasional, akibatnya peserta didik menjadi sosok yang pasif serta kurangnya rasa percaya diri.

Pendekatan pembelajaran tersebut tentunya perlu dikembangkan, bukan lagi proses belajar yang bersifat teacher centris di mana hanya mengandalkan informasi dari guru, namun haruslah berkembang menjadi proses belajar mengajar yang berorientasi pada peserta didik atau student centris. ${ }^{24}$

Proses pembelajaran student centris para peserta didik diarahkan untuk lebih banyak mendapatkan informasi secara pribadi. Dengan pendekatan tersebut peserta didik akan terlatih bersikap kreatif, mandiri, produktif di mana sikap-sikap tersebut akan dibutuhkan untuk menghadapi masyarakat dalam era globalisasi. Dalam strategi pembelajaran tersebut maka peran guru diperlukan sebagai motivator (pendorong/ 
Hadiyatan Wasilah - Upaya Mengatasi Tantangan...

penggerak), desainer (perancang), katalisator (penghubung), guidance (pemandu), evaluator (penilai) serta justificator (pembenar) $)^{25}$

\section{c. Penanaman serta Penerapan Nilai- Nilai Keislaman}

Fenomena globalisasi sedikit banyak berdampak pada perilaku masyarakat, contoh kecilnya saja berkat mudahnya mengakses informasi serta canggihnya teknologi menjadikan masyarakat dapat mengakses konten-konten yang merusak nilai-nilai norma sehingga munculnya seks bebas, penyalahgunaan obat terlarang, perilaku anarkis, serta runtuhnya nilai-nilai moral di masyarakat

Menghadapi fenomena tersebut barang tentu menjadi pekerjaan rumah besar bagi dunia pendidikan terkhusus pendidikan Islam yang tentunya lebih diharapkan masyarakat untuk menjadi pembentuk serta penanam nilai-nilai moral islami bagi peserta didik agar tidak terjerat gemerlap arus globalisasi yang semakin hari semakin mencekam.

Pendidikan Islam dalam hal ini tentu perlu menanamkan serta merealisasikan nilai-nilai moral islami yang dengannya diharapkan dapat memberi benteng

\footnotetext{
25 Abuddin Nata, Manajemen pendidikan....., hlm. 102-103

${ }^{26}$ Ibid, hlm. 107
}

pertahanan bagi peserta didik dalam menghadapi gejolak bahaya yang ditimbulkan oleh globalisasi.

Ajaran-ajaran serta penerapan akhlak serta ketauhidan tentunya perlu ditanamkan pada seluruh kegiatan belajar mengajar di lembaga pendidikan Islam. ${ }^{26}$ Karena dalam ajaran Islam telah mengatur segala pedoman kehidupan, seperti adl (keadilan), ihsan (berbuat baik), taqwa (merasakan kehadiran Allah yang melahirkan kepatuhan akan perintah serta larangannya). ${ }^{27}$

Penanaman nilai-nilai Islami tersebut haruslah diiringi dengan pemberian contoh yang baik (uswah hasanah) seluruh masyarakat di dalam lembaga mulai dari guru sampai tenaga kependidikan. Dalam hal ini terdapat kutipan tentang bagaimana harusnya implementasi pendidikan intelektual serta akhlak sehingga mampu menghasilkan peserta didik yang berkualitas:

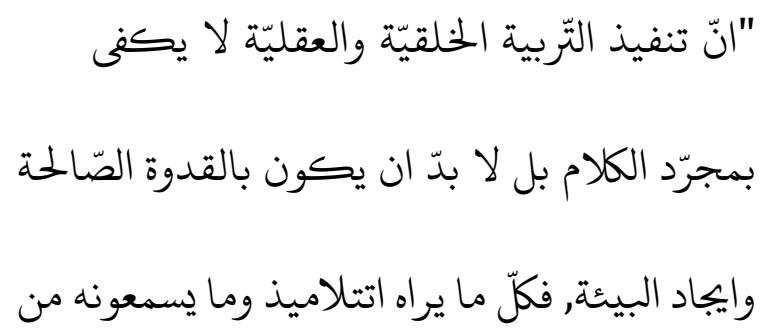
27 Israr, Ahmad Khan, Towards Understanding.....(diakses pada tanggal 04 November 2019, pukul 13.52 WIB)




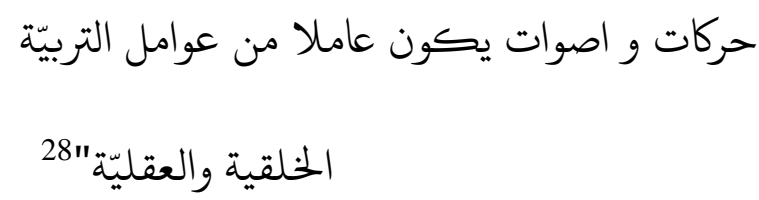

Kutipan di atas menjelaskan bahwa implementasi atau penerapan pendidikan moral serta intelektual bagi peserta didik tidak cukup hanya dengan perkataan atau perintah saja namun haruslah dengan menjadi contoh yang baik dan dengan dukungan lingkungan yang kondusif, karena apa-apa yang dilihat, dan didengar oleh peserta didik adalah faktor keberhasilan dalam proses pendidikan.

Olehnya bagi guru dalam pendidikan Islam hendaknya selalu berakhlakul karimah dalam kehidupan pribadi maupun sosial sesuai dengan pernyataan yang sering disampaikan kepada peserta didik. Dengan hal ini akan diteladani perilaku guru yang disaksikan peserta didik di dalam lingkungan sekolah, dengan harapan terlahirnya generasi yang cerdas bukan hanya dalam segi intelektual namun juga moral.

\section{KESIMPULAN}

Upaya pendidikan Islam dalam menghadapi abad XXI yakni lewat derasnya arus globalisasi yang menimbulkan kecemasan individu akibat mudahnya mendapatkan informasi serta komunikasi yang menimbulkan dampak seperti pergaulan bebas, hilangnya norma-norma ketimuran, serta dihinggapinya masyarakat akan pandangan materialisme, hedonisme yang menjadikan manusia jauh dari TuhanNya.

Melihat fenomena tersebut upaya yang dapat dilakukan oleh pendidikan Islam adalah sebagai berikut: 1) membangun orientasi dan visi pendidikan Islam; 2) integrasi antara ilmu agama dan umum; 3) pengembangan tradisi akademik; 4) reorientasi visi dan misi guru; 5) strategi pembelajaran; 6) penanaman serta penerapan nilai-nilai keislaman.

\section{DAFTAR PUSTAKA}

Buseri, Kamrani, 2003, Antologi Pendidikan Islam dan Dakwah, Pemikiran Teoritis Praktis Kontemporer, Yogyakarta: UII Press

Ismail, Faisal, 2017, Paradigma Pendidikan Islam Analisis Historis, Kebijakan dan Keilmuan, Bandung: Rosda

Khan, Israr Ahmad, Towards Understanding Islamic Paradigm of Education, https://i-epistemology.net/ subjects/

\footnotetext{
${ }^{28}$ Rif'at Husnul Maafi, Agus Budiman, dkk, Ushulu al-Tarbiyah wa al-Ta'lim al-juz Awwal, (Ponorogo: Darussalam Press, 2007), hlm. 6-7
} 
Hadiyatan Wasilah - Upaya Mengatasi Tantangan...

education/item/606-towards-under

standing-islamic-paradigm-of-

education. html, (diakses pada tanggal

31 Oktober 2019, pukul 18.30 WIB)

Kuntowijoyo, 2007, Islam Sebagai Ilmu

Epistemologi, Metodologi, dan Etika,

Yogyakarta: Tiara Wacana

Maafi, Rif'at Husnul, Budiman, Agus, dkk, 2007, Ushulu al-Tarbiyah wa al-Ta'lim

al-juz Awwal, Ponorogo: Darussalam Press

Muhaimin, 2011, Pemikiran dan Aktualisasi Pengembangan Pendidikan Islam, (Jakarta: Raja Grafindo Persada
Nata, Abuddin, 2012, Kapita Selekta Pendidikan Islam Isu-Isu Kontemporer tentang Pendidikan Islam, Depok: Raja Grafindo Persada. , 2012, Manajemen pendidikan Mengatasi Kelemahan pendidikan di Indonesia, Jakarta: Kencana

Qomar, Mujamil, 2013, Strategi Pendidikan Islam, Jakarta: Erlangga.

Zainal, Veitzal Rivai, Bahar, Fauzi, 2013, Islamic Education Management Dari Teoritik ke Praktik Mengelola Pendidikan Secara Profesional dalam Perspektif Islam, Depok: Raja Grafindo 
Jurnal TAMADDUN - FAI UMG. Vol. XXI. No.1 / Januari 2020 